\title{
EFFECT OF SEED SOAKING AND FOLIAR SPRAYING WITH SELENIUM ON THE GROWTH AND YIELD OF LETTUCE UNDER SALINE STRESS
}

\author{
Shalaby, Osama A. * and Mansour E. Ramadan \\ Department of Plant Production, Desert Research Center, El- \\ Matareya, Cairo, Egypt \\ *E-mail: o.a.shalaby@gmail.com
}

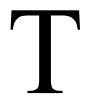

he implementation of proper agricultural practices is important for reducing the effect of salt stress in plants. Therefore, this experiment was conducted in 2014/2015 and 2015/2016 seasons at Ras Sudr station of Desert Research Center, South Sinai Governorate, Egypt, to determine the most effective selenium (Se) dose and application method on lettuce plants Bruma cultivar under salt stress conditions. Six different Se treatments; $\mathrm{Se} 0$ (without application as a control), Se1 (seed soaking in $30 \mu \mathrm{mol}{ }^{-1}$ for $12 \mathrm{~h}$ ), Se2 (seed soaking in $50 \mu \mathrm{mol} \mathrm{l}^{-1}$ for $12 \mathrm{~h}$ ), Se3 (foliar application of $10 \mu \mathrm{mol} \mathrm{l}^{-1}$ ), Se4 (foliar application of 20 $\mu \mathrm{mol} \mathrm{l}^{-1}$ ) and Se5 (foliar application of $30 \mu \mathrm{mol} 1^{-1}$ ) were applied. The results showed that Se provision through both of the tested methods improved the plant leaf number, chlorophyll content, as well as $\mathrm{N}, \mathrm{P}, \mathrm{K}$ and $\mathrm{Ca}$ concentrations in the leaves, when compared with the control treatment. Moreover, $\mathrm{Na}$ content decreased in the leaves, which were treated than those of the control treatment. The plants grown under the Se treatments had larger heads and higher yields than the untreated plants. Foliar spraying was the most effective method of Se application of the lettuce plants, and the best results were obtained with the foliar spraying treatment at $20 \mu \mathrm{mol} \mathrm{l}^{-}$ 1 sodium selenate. These results suggest that applying the appropriate dose of Se via foliar spraying has the potential for use as an efficient and practical method of improving plant growth and enhancing salt-stress resistance in lettuce plants.

Keywords: Lactuca sativa, growth, salinity, sodium selenate, fortification, nutrient contents

Salinity is one of the most deleterious abiotic environmental factors affecting plants. It represents an obstacle that limits cultivation and productivity of vegetable crops, especially sensitive cultivars. This problem is more conspicuous in arid or semi-arid regions. Plant growth performance may be adversely affected by salinity because of the accumulation of soluble 
salts in the root zone, which reduce the plant's ability to absorb water and necessary nutrients from the soil thereby causing water deficit, competitive effects on ion absorption, osmotic stress, ion-specific toxicity and disruption of the nutrient transport within plants (Unlukara et al., 2008 and KeLing et al., 2013).

Selenium (Se) is an essential micronutrient for maintaining human and animal health. Although, it is not yet considered an essential element for higher plants, this status is recently given augmenting (Diao et al., 2014). Studies have shown the importance and benefits of Se for plants, particularly under abiotic stress, where it acts as an antioxidant and ameliorates the effects and protects plants under deleterious conditions such as salt stress (KeLing et al., 2013; Kaur and Nayyar, 2015 and Mozafariyan et al., 2016), also drought stress (Yao et al., 2009 and Nawaz et al., 2015).

The beneficial effects of Se at low concentrations in plants, which include improvements in vegetative growth and increasing in the quality and production of vegetable crops, have been reported in many species, such as lettuce (Ramos et al., 2010; Melek et al., 2012 and Esringu et al., 2015), broccoli (Ghasemi et al., 2016), tomato (Mozafariyan et al., 2016), melon (KeLing et al., 2013) and potato (Poggi et al., 2000). Moreover, Pezzarossa et al. (2012) and Zhu et al. (2017) demonstrated that Se treatments represent a promising strategy for delaying ripening and senescence of fruits and maintaining fruit quality, while decreasing the postharvest period losses and extending the shelf life of crops, especially in leafy vegetables. Moreover (Ramos et al., 2010; Pezzarossa et al., 2012; Khaliq et al., 2015 and Mao et al., 2015) reported that low concentrations of Se enhance plant growth, whereas high concentrations have a toxic effect on plants. However, the optimal and effective dose of Se depends on plant species and cultivation conditions (Apolonia et al., 2015). Selenium deficiency has a direct negative effect on human health. Therefore, fortifying crops with selenium may be benefit for plants and provide a necessary element for human nutrition (Feng et al., 2013).

The mechanisms underlying the effect of Se on plant performance are poorly understood, especially under stress conditions (Diao et al., 2014; Apolonia et al., 2015 and Sun et al., 2016), although possible explanations have been provided the positive impact of Se on plants. Se application at low concentrations might enhances plant growth under stress conditions through various mechanisms, for example, Se might reduce the osmotic potential and maintain turgor, enhance the transpiration rate and promote the accumulation of total soluble sugars and free amino acids (Nawaz et al., 2015) or the activity of antioxidant enzymes (Ramos et al., 2010 and Khaliq et al., 2015). Also, it increases the carotenoid and proline contents (Yao et al., 2009), enhances photosynthetic pigments and decreases chloride ion contents (Hawrylak-Nowak, 2009), also reduces membrane damage and reactive oxygen species (ROS) (Djanaguiraman et al., 2010), adjusts the uptake and 
redistribution of essential elements or maintain the ion balance and structural integrity of plant cells (Feng et al., 2013). Foliar application of Se is the most efficient, economic and safe method for enriching the Se content of plant biomass, also ensuring that plants represent a rich source of dietary Se (Poggi et al., 2000; Hawrylak-nowak, 2009 and Pezzarossa et al., 2012). Ramos et al. (2010) showed that lettuce plants can be used in the Se biofortification programs as an efficient method to increase the human intake of this element.

Lettuce (Lactuca sativa) represents one of the most important leafy vegetable crops and is affiliated with the Asteraceae family. Lettuce was chosen for this study as representative of vegetables that are sensitive to salt stress. The production of lettuce is not affected even at a salinity level of 1.1 $\mathrm{dS} \mathrm{m} \mathrm{m}^{-1}$ and it shows a negative slope of $9.3 \%$ for each unit of added salinity above this threshold value (Unlukara et al., 2008). Salt stress restricts lettuce growth performance and cause a reduction in the quantity and quality of vegetable crops (Melek et al., 2012 and Kim et al., 2016).

The aim of this work was to evaluate the impact of Se on growth and productivity of lettuce plant under salt stress conditions, using two fortification methods, seed soaking and foliar spraying at various concentrations. The goal was to determine the best application method and optimum level of Se to develop an effective application protocol to mitigate the adverse effects of salt stress on lettuce plant.

\section{MATERIALS AND METHODS}

The experiment was conducted in 2014/2015 and 2015/2016 at the experimental farm of Ras Sudr Station, Desert Research Center, which is located in the South Sinai Governorate, Egypt (30 34' N, 31 $34^{\prime}$ E). Lettuce seeds of the Bruma cultivar were provided by the RijkZwaan Company and sown during the first ten days of September in both seasons. The growth of seedlings was monitored for a period of 40 days. Subsequently, the seedlings were transplanted to the experimental area in rows spaced $50 \mathrm{~cm}$ apart, with $30 \mathrm{~cm}$ spacing between seedlings. The soil physical and chemical properties of the experimental field are presented in table (1). The soil analysis was conducted according to Rebecca (2004). A drip irrigation system was used with saline water $(\mathrm{EC} 7.03 \mathrm{mS} \mathrm{cm}$ ) pumped from ground well.

The experimental design was a randomized complete block design with three replicates. The treatments were as follows: $\mathrm{Se} 0$ (without application as a control), Se1 (seed soaking with $30 \mu \mathrm{mol}^{-1}$ for $12 \mathrm{~h}$ ), Se2 (seed soaking with $50 \mu \mathrm{mol} \mathrm{l}^{-1}$ for $12 \mathrm{~h}$ ), Se3 (foliar application with 10 $\mu \mathrm{mol} \mathrm{l}^{-1}$ ), Se4 (foliar application with $20 \mu \mathrm{mol}^{-1}$ ) and Se5 (foliar application with $30 \mu \mathrm{mol}^{-1}$ ). The lettuce seeds were divided into three groups. The first group was soaked in distilled water without selenium and served as a control. The second group, the seeds were soaked in $30 \mu \mathrm{mol} \mathrm{l}^{-1} \mathrm{Se}$ for $12 \mathrm{~h}$. 
The third group, seeds were soaked in $50 \mu \mathrm{mol}^{-1} \mathrm{Se}$ for $12 \mathrm{~h}$. After the presoaking treatment, the seeds were removed and their surface dried at room temperature to facilitate the seed sowing process and then sown in foam trays. Foliar spraying with Se was performed a total of 3 times throughout the cropping season, with the first treatment performed before the seedlings were transplanted, and a 10 day interval between the subsequent foliar treatments. All experimental plots received irrigation, pesticide and fertilizer as recommended by the Egyptian Ministry of Agriculture for lettuce cultivation.

Table (1). Mechanical and chemical properties of the experimental soil.

\begin{tabular}{ccccccccc}
\hline Depth (cm) & $\mathbf{p H}$ & $\begin{array}{c}\mathbf{E C} \\
\left(\mathbf{m S} \cdot \mathbf{c m}^{-1}\right)\end{array}$ & $\begin{array}{c}\mathbf{C a C O}_{3} \\
(\boldsymbol{\%})\end{array}$ & $\begin{array}{c}\text { Silt } \\
(\boldsymbol{\%})\end{array}$ & $\begin{array}{c}\text { Sand } \\
(\boldsymbol{\%})\end{array}$ & $\begin{array}{c}\text { Clay } \\
(\boldsymbol{\%})\end{array}$ & $\begin{array}{c}\text { Class } \\
\text { texture }\end{array}$ \\
\hline $0-30$ & 7.7 & 8.65 & 56.99 & 8.05 & 81.28 & 10.67 & Sandy Loam \\
$30-60$ & 7.4 & 7.90 & 52.48 & 7.59 & 86.08 & 6.33 & \\
\hline \multicolumn{7}{c}{ Soluble anions $\left(\mathbf{m g} \cdot \mathbf{1 0 0} \mathbf{~ g}^{-1}\right)$} & \multicolumn{5}{c}{ Soluble cations $\left(\mathbf{m g} \cdot \mathbf{1 0 0} \mathbf{~ g}^{-1}\right)$} & \\
\hline $0-30$ & $\mathrm{CO}^{-2}{ }_{3}$ & $\mathrm{HCO}^{-3}$ & $\mathrm{SO}^{-2}{ }_{4}$ & $\mathrm{Cl}^{-}$ & $\mathrm{Ca}^{+2}$ & $\mathrm{Mg}^{+2}$ & $\mathrm{Na}^{+}$ & $\mathrm{K}^{+}$ \\
\hline $30-60$ & 0.00 & 105 & 2832 & 2276 & 767 & 335 & 1353 & 79 \\
& 0.00 & 61 & 3133 & 1828 & 618 & 268 & 1513 & 4 \\
\hline
\end{tabular}

At harvest, five plants from each plot were sampled to conduct vegetative, chemical and yield measurements. The plant samples were rinsed in distilled water and then blotted to remove excess water. The vegetative and crop measurements included the plant leaf number, chlorophyll content (Inada, 1985), head diameter and fresh weight and total yield per hectar. The chemical contents of the leaves (e.g., dry matter, N, P, K, Ca and $\mathrm{Na}$ ) were estimated. The leaf samples were rinsed in distilled water and then dried in an oven at $70^{\circ} \mathrm{C}$ for $48 \mathrm{~h}$. The nitrogen content was determined using the micro-Kjeldahl method (Jackson, 1973); the phosphorus content was determined by the ammonium-molybdate method as described by Jackson (1973). Potassium and sodium contents were quantified using flame photometer (Irri, 1976). The calcium content was estimated photometerically according to the method of Brown and Lilliland (1964).

The data were statistically analyzed by an analysis of variance according to the method described by Gomez and Gomez (1984) using the COSTAT software package. Significant differences were determined using the least significant difference test (L.S.D.) at $p \leq 0.05$ (Snedecor and Cochran, 1980). 


\section{RESULTS AND DISCUSSION}

\section{Plant Leaf Number and Leaf Chlorophyll Content}

The plant leaf number and leaf chlorophyll content as influenced by the pre-soaking of seeds and foliar spraying of Se are shown in table (2). The results showed that the plant leaf number and leaf chlorophyll content were significantly different depending on the method and rate of Se application and these parameters were generally increased under the Se fortification when compared with the untreated plants. The highest leaf number and leaf chlorophyll content values were observed in the plants treated with foliar spraying at $20 \mu \mathrm{mol} \mathrm{l^{-1 }}$, whereas the lowest values were observed in the control treatment (without $\mathrm{Se}$ ) in both growing seasons. A similar positive impact of Se was observed by Ghasemi et al. (2016) and Mozafariyan et al. (2016), although a marked effect on the chlorophyll content was not observed by Haghighi et al. (2016). Additionally, Mao et al. (2015) reported that $\mathrm{Se}$ at low concentrations enhances the growth of broccoli plants, whereas high concentrations discourage plant growth. These findings demonstrated that Se fortification of plants can serve efficiently as a mitigating agent against the deleterious effects of salt stress. The positive effect of Se on plant growth and chlorophyll content may be attributed to the improvement of photosynthetic capacity and the greater synthesis of carbohydrates and proteins, which increase plant growth (Hawrylak-Nowak, 2008a; and Apolonia et al., 2015). Also, Se applications can improve plant performance and alleviate the adverse effects of salt stress by improving the integrity of cell membranes by increasing the relative leaf water content and the photosynthetic pigments concentration to provide protection from free radicals (Mozafariyan et al., 2016). Furthermore, Se applications can induce higher plant root volume, which may increase the absorption efficiency of water and elements (Haghighi et al., 2014). The increase in the proline content and enzymatic activities could decrease the damage of membranes via enhancing antioxidant defense under stress conditions (Akladious, 2012) and may also promote certain plant growth parameters, such as the plant leaf number and leaf chlorophyll content in the Se-treated plants.

\section{Yield and its Components}

Selenium applications can offset the negative impact of salt stress on lettuce yield and its components. The Se seed soaking and foliar spraying treatments caused a significant elevation in total yield and improved the yield characteristics, such as head diameter and fresh weight (Table 2). However, the foliar spraying treatment was the most effective method of Se enrichment. The application of foliar spray at $20 \mu \mathrm{mol} \mathrm{Se} 1^{-1}$ resulted in the highest values of head diameter and fresh weight, as well as total yield, whereas the control treatment resulted in the lowest values in both growing 
seasons. These results are consistent with those of Esringu et al. (2015) and Ghasemi et al. (2016). These benefits might be related to the influence of Se on the plant water status by maintaining turgor and gas exchange and enhancing the activity of osmoprotectants and antioxidant machinery under stress conditions (Nawaz et al., 2015), Additionally, Se applications can induce protective responses against salt stress by enhancing antioxidative activity, increasing the accumulation of proline and photosynthetic pigments, besides decreasing the chloride ion content (Hawrylak-Nowak, 2009), thereby resulting in higher plant growth and chlorophyll content (Table 2), which leads to increase in plant yield.

Table (2). Effect of selenium as a seed soaking and foliar spraying on plant leaf number, chlorophyll content, head diameter, head fresh weight and total yield of lettuce in 2014/2015 and 2015/2016 seasons.

\begin{tabular}{|c|c|c|c|c|c|}
\hline \multirow{2}{*}{$\begin{array}{l}\text { Treatment } \\
\text { Selenium } \\
\quad(\mathbf{S e})\end{array}$} & \multicolumn{5}{|c|}{ Character } \\
\hline & $\begin{array}{l}\text { Plant leaf } \\
\text { number }\end{array}$ & $\begin{array}{l}\text { Chlorophyll } \\
\text { reading } \\
\text { (Spad) }\end{array}$ & $\begin{array}{c}\text { Head } \\
\text { diameter } \\
(\mathbf{c m})\end{array}$ & $\begin{array}{l}\text { Head fresh } \\
\text { weight } \\
\text { (kg) }\end{array}$ & $\begin{array}{l}\text { Total yield } \\
\left(\mathrm{mg} \mathrm{ha}^{-1}\right)\end{array}$ \\
\hline & & & $2014 / 2015$ & & \\
\hline Se0 & $17.67 \pm 3.06^{\mathrm{d}}$ & $25.90 \pm 1.56^{\mathrm{d}}$ & $11.98 \pm 0.29^{\mathrm{f}}$ & $0.28 \pm 0.06^{\mathrm{c}}$ & $17.38 \pm 1.96^{\mathrm{d}}$ \\
\hline Se1 & $24.00 \pm 4.00^{\mathrm{c}}$ & $30.70 \pm 2.16^{\mathrm{c}}$ & $14.88 \pm 1.04^{\mathrm{e}}$ & $0.37 \pm 0.03^{b}$ & $20.48 \pm 2.83^{\mathrm{c}}$ \\
\hline $\mathrm{Se} 2$ & $28.33 \pm 5.03^{b}$ & $29.80 \pm 1.06^{\mathrm{c}}$ & $15.92 \pm 0.87^{\mathrm{d}}$ & $0.38 \pm 0.04^{b}$ & $20.53 \pm 0.22^{\mathrm{c}}$ \\
\hline Se3 & $25.33 \pm 3.06^{\mathrm{bc}}$ & $30.43 \pm 0.95^{\mathrm{c}}$ & $17.07 \pm 0.39^{\mathrm{c}}$ & $0.38 \pm 0.01^{b}$ & $21.65 \pm 1.31^{\mathrm{bc}}$ \\
\hline Se4 & $35.33 \pm 3.06^{\mathrm{a}}$ & $39.83 \pm 0.50^{\mathrm{a}}$ & $20.00 \pm 0.61^{\mathrm{a}}$ & $0.45 \pm 0.03^{\mathrm{a}}$ & $23.33 \pm 0.58^{\mathrm{a}}$ \\
\hline \multirow[t]{2}{*}{ Se5 } & $34.67 \pm 3.06^{\mathrm{a}}$ & $36.43 \pm 1.68^{b}$ & $18.11 \pm 0.47^{b}$ & $0.41 \pm 0.04^{b}$ & $22.30 \pm 0.09^{\mathrm{ab}}$ \\
\hline & & & $\underline{2015 / 2016}$ & & \\
\hline Se0 & $21.67 \pm 3.06^{\mathrm{e}}$ & $29.90 \pm 0.87^{\mathrm{e}}$ & $\overline{12.99 \pm 0.40^{\mathrm{e}}}$ & $0.32 \pm 0.03^{\mathrm{e}}$ & $19.26 \pm 0.37^{\mathrm{e}}$ \\
\hline Se1 & $26.67 \pm 1.15^{\mathrm{d}}$ & $34.57 \pm 0.81^{\mathrm{d}}$ & $15.60 \pm 0.73^{\mathrm{d}}$ & $0.39 \pm 0.02^{\mathrm{d}}$ & $21.75 \pm 0.51^{\mathrm{d}}$ \\
\hline $\mathrm{Se} 2$ & $30.00 \pm 2.00^{\mathrm{c}}$ & $36.50 \pm 1.20^{\mathrm{c}}$ & $16.06 \pm 0.38^{\mathrm{d}}$ & $0.39 \pm 0.02^{\mathrm{d}}$ & $21.88 \pm 0.38^{\mathrm{d}}$ \\
\hline $\mathrm{Se} 3$ & $27.33 \pm 1.15^{\mathrm{d}}$ & $36.83 \pm 0.76^{\mathrm{c}}$ & $17.20 \pm 0.41^{\mathrm{c}}$ & $0.42 \pm 0.02^{\mathrm{c}}$ & $22.90 \pm 0.05^{\mathrm{c}}$ \\
\hline Se4 & $38.33 \pm 3.06^{\mathrm{a}}$ & $41.83 \pm 0.83^{\mathrm{a}}$ & $21.09 \pm 0.42^{\mathrm{a}}$ & $0.50 \pm 0.03^{\mathrm{a}}$ & $25.18 \pm 0.15^{\mathrm{a}}$ \\
\hline \multirow[t]{2}{*}{ Se5 } & $36.00 \pm 2.00^{\mathrm{b}}$ & $40.60 \pm 1.25^{\mathrm{b}}$ & $19.42 \pm 1.23^{\mathrm{b}}$ & $0.46 \pm 0.01^{b}$ & $24.06 \pm 0.73^{\mathrm{b}}$ \\
\hline & & & $\underline{P \text { value }}$ & & \\
\hline $2014 / 2015$ & $0.00(* * *)$ & $0.00(* * *)$ & $0.00(* * *)$ & $0.00(* * *)$ & $0.00(* * *)$ \\
\hline $2015 / 2016$ & $0.00(* * *)$ & $0.00(* * *)$ & $0.00(* * *)$ & $0.00(* * *)$ & $0.00(* * *)$ \\
\hline
\end{tabular}

$\mathrm{Se} 0=$ control Se1= soaking by $30 \mu \mathrm{mol} \mathrm{l}^{-1}$ for $12 \mathrm{~h} \mathrm{Se} 2=$ soaking by $50 \mu \mathrm{mol} \mathrm{l}^{-1}$ for 12 $\mathrm{h}, \mathrm{Se} 3=$ foliar by $10 \mu \mathrm{mol} \mathrm{l}{ }^{-1}$, Se4= foliar by $20 \mu \mathrm{mol} \mathrm{l}^{-1}$, Se $5=$ foliar by $30 \mu \mathrm{mol} \mathrm{l}^{-1}$ 


\section{Chemical Contents of Lettuce Heads}

As shown in tables (3 and 4), Se supplementation by soaking and foliar spraying resulted in higher contents of dry matter, N, P, K and $\mathrm{Ca}$ in the lettuce plants in both experimental seasons. The highest values were obtained when the plants were treated with foliar spray at $20 \mu \mathrm{mol} 1^{-1}$. The increases were significant when compared with control treatment in both seasons. These results are consistent with the work of Hawrylak-Nowak (2008b), Abul-Soud and Abd-Elrahman (2016) and Castillo-Godina et al. (2016). The effect of Se on plants depends mainly on its concentration. According to Hamilton (2004) Se has three levels of biological activity: (1) Trace concentrations are required for normal growth and development; (2) Moderate concentrations can be stored to maintain homeostatic functions; and (3) High concentrations may result in toxic effects. The doses of Se applied were appropriate for modifying the uptake and accumulation of minerals that are important for metabolism (Kopsell et al., 2000 and Pazurkiewicz-Kocot et al., 2003). Moreover, Se has been shown to have a positive impact on the activity and permeability of the cellular membrane, which may represent one of the earliest symptoms of the influence of Se on plants (Kinraide, 2003).

Table (3). Effect of selenium as a seed soaking and foliar spraying on dry matter, $\mathrm{N}$ and $\mathrm{P}$ contents of lettuce in 2014/2015 and 2015/2016 seasons.

\begin{tabular}{ccccccc}
\hline Treatment & \multicolumn{6}{c}{ Character } \\
\hline $\begin{array}{c}\text { Selenium } \\
(\text { Se })\end{array}$ & \multicolumn{2}{c}{$\begin{array}{c}\text { Dry matter } \\
(\boldsymbol{\%})\end{array}$} & \multicolumn{2}{c}{$\begin{array}{c}\mathbf{N} \\
(\boldsymbol{\%})\end{array}$} & \multicolumn{2}{c}{$\begin{array}{c}\text { P } \\
(\boldsymbol{\%})\end{array}$} \\
\cline { 2 - 7 } & $\mathbf{2 0 1 4 / 2 0 1 5}$ & $\mathbf{2 0 1 5 / 2 0 1 6}$ & $\mathbf{2 0 1 4 / 2 0 1 5}$ & $\mathbf{2 0 1 5 / 2 0 1 6}$ & $\mathbf{2 0 1 4 / 2 0 1 5}$ & $\mathbf{2 0 1 5 / 2 0 1 6}$ \\
\hline Se0 & $2.18 \pm 0.32^{\mathrm{d}}$ & $2.40 \pm 0.20^{\mathrm{e}}$ & $1.52 \pm 0.13^{\mathrm{e}}$ & $1.71 \pm 0.14^{\mathrm{d}}$ & $0.37 \pm 0.05^{\mathrm{d}}$ & $0.44 \pm 0.05^{\mathrm{e}}$ \\
Se1 & $2.72 \pm 0.12^{\mathrm{c}}$ & $3.02 \pm 0.14^{\mathrm{d}}$ & $1.82 \pm 0.09^{\mathrm{d}}$ & $2.35 \pm 0.17^{\mathrm{c}}$ & $0.50 \pm 0.07^{\mathrm{c}}$ & $0.55 \pm 0.05^{\mathrm{d}}$ \\
Se2 & $2.91 \pm 0.18^{\mathrm{b}}$ & $3.21 \pm 0.19^{\mathrm{c}}$ & $2.06 \pm 0.26^{\mathrm{c}}$ & $2.34 \pm 0.09^{\mathrm{c}}$ & $0.52 \pm 0.06^{\mathrm{c}}$ & $0.60 \pm 0.03^{\mathrm{c}}$ \\
Se3 & $3.02 \pm 0.23^{\mathrm{b}}$ & $3.20 \pm 0.14^{\mathrm{c}}$ & $2.16 \pm 0.35^{\mathrm{c}}$ & $2.60 \pm 0.09^{\mathrm{b}}$ & $0.57 \pm 0.03^{\mathrm{b}}$ & $0.61 \pm 0.07^{\mathrm{c}}$ \\
Se4 & $3.26 \pm 0.10^{\mathrm{a}}$ & $3.81 \pm 0.13^{\mathrm{a}}$ & $2.60 \pm 0.09^{\mathrm{a}}$ & $3.09 \pm 0.27^{\mathrm{a}}$ & $0.63 \pm 0.03^{\mathrm{a}}$ & $0.73 \pm 0.04^{\mathrm{a}}$ \\
Se5 & $3.08 \pm 0.07^{\mathrm{b}}$ & $3.45 \pm 0.17^{\mathrm{b}}$ & $2.41 \pm 0.10^{\mathrm{b}}$ & $2.69 \pm 0.22^{\mathrm{b}}$ & $0.60 \pm 0.07^{\mathrm{ab}}$ & $0.67 \pm 0.07^{\mathrm{b}}$ \\
P value & $0.00(* * *)$ & $0.00(* * *)$ & $0.00(* * *)$ & $0.00(* * *)$ & $0.00(* * *)$ & $0.00(* * *)$ \\
\hline
\end{tabular}

$\mathrm{Se} 0=$ control, Se1= soaking by $30 \mu \mathrm{mol} \mathrm{l}^{-1}$ for $12 \mathrm{~h}, \mathrm{Se} 2=$ soaking by $50 \mu \mathrm{mol} \mathrm{l}^{-1}$ for 12 $\mathrm{h}, \mathrm{Se} 3=$ foliar by $10 \mu \mathrm{mol} \mathrm{l} \mathrm{l}^{-1}$, Se $4=$ foliar by $20 \mu \mathrm{mol} \mathrm{l}^{-1}$, Se $5=$ foliar by $30 \mu \mathrm{mol} \mathrm{l}^{-1}$ 
Table (4). Effects of selenium as a seed soaking and foliar spraying treatments on the $\mathrm{K}, \mathrm{Ca}$ and $\mathrm{Na}$ content of lettuce plants in the 2014/2015 and 2015/2016 seasons.

\begin{tabular}{ccccccc}
\hline Treatment & \multicolumn{6}{c}{ Character } \\
$\begin{array}{c}\text { Selenium } \\
\text { (Se) }\end{array}$ & \multicolumn{2}{c}{$\begin{array}{c}\text { K } \\
(\boldsymbol{\%})\end{array}$} & \multicolumn{2}{c}{$\begin{array}{c}\text { Ca } \\
(\boldsymbol{\%})\end{array}$} & \multicolumn{2}{c}{$\begin{array}{c}\text { Na } \\
(\boldsymbol{\%})\end{array}$} \\
\cline { 2 - 7 } & $\mathbf{2 0 1 4 / 2 0 1 5}$ & $\mathbf{2 0 1 5 / 2 0 1 6}$ & $\mathbf{2 0 1 4 / 2 0 1 5}$ & $\mathbf{2 0 1 5 / 2 0 1 6}$ & $\mathbf{2 0 1 4 / 2 0 1 5}$ & $\mathbf{2 0 1 5 / 2 0 1 6}$ \\
\hline Se0 & $2.35 \pm 0.67^{\mathrm{e}}$ & $2.94 \pm 0.22^{\mathrm{e}}$ & $0.40 \pm 0.07^{\mathrm{d}}$ & $0.49 \pm 0.05^{\mathrm{d}}$ & $2.11 \pm 0.22^{\mathrm{a}}$ & $2.34 \pm 0.18^{\mathrm{a}}$ \\
Se1 & $2.94 \pm 0.13^{\mathrm{d}}$ & $3.26 \pm 0.16^{\mathrm{d}}$ & $0.61 \pm 0.06^{\mathrm{c}}$ & $0.72 \pm 0.13^{\mathrm{c}}$ & $1.92 \pm 0.15^{\mathrm{b}}$ & $1.97 \pm 0.13^{\mathrm{b}}$ \\
Se2 & $3.36 \pm 0.14^{\mathrm{c}}$ & $3.60 \pm 0.27^{\mathrm{c}}$ & $0.72 \pm 0.14^{\mathrm{c}}$ & $0.81 \pm 0.14^{\mathrm{c}}$ & $1.75 \pm 0.12^{\mathrm{b}}$ & $1.82 \pm 0.16^{\mathrm{b}}$ \\
Se3 & $3.19 \pm 0.16^{\mathrm{cd}}$ & $3.40 \pm 0.14^{\mathrm{d}}$ & $0.72 \pm 0.08^{\mathrm{c}}$ & $0.84 \pm 0.07^{\mathrm{c}}$ & $1.79 \pm 0.09^{\mathrm{b}}$ & $1.83 \pm 0.09^{\mathrm{b}}$ \\
Se4 & $4.08 \pm 0.33^{\mathrm{a}}$ & $4.21 \pm 0.06^{\mathrm{a}}$ & $1.06 \pm 0.19^{\mathrm{a}}$ & $1.22 \pm 0.06^{\mathrm{a}}$ & $1.15 \pm 0.33^{\mathrm{d}}$ & $1.32 \pm 0.16^{\mathrm{d}}$ \\
Se5 & $3.65 \pm 0.20^{\mathrm{b}}$ & $4.05 \pm 0.18^{\mathrm{b}}$ & $0.90 \pm 0.02^{\mathrm{b}}$ & $1.08 \pm 0.18^{\mathrm{b}}$ & $1.53 \pm 0.08^{\mathrm{c}}$ & $1.61 \pm 0.15^{\mathrm{c}}$ \\
P value & $0.00(* * *)$ & $0.00(* * *)$ & $0.00(* * *)$ & $0.00(* * *)$ & $0.00(* * *)$ & $0.00(* * *)$ \\
\hline
\end{tabular}

$\mathrm{Se} 0=$ control $\mathrm{Se} 1=$ soaking by $30 \mu \mathrm{mol} \mathrm{l}^{-1}$ for $12 \mathrm{~h} \mathrm{Se} 2=$ soaking by $50 \mu \mathrm{mol} \mathrm{l}^{-1}$ for 12 $\mathrm{h}, \mathrm{Se} 3=$ foliar by $10 \mu \mathrm{mol} \mathrm{l} \mathrm{l}^{-1}$, Se $4=$ foliar by $20 \mu \mathrm{mol} \mathrm{l}^{-1}$, Se $5=$ foliar by $30 \mu \mathrm{mol} \mathrm{l}^{-1}$

The results showed that significant reduction in Na content occurred in the lettuce plants under Se application. The lowest values were observed with the foliar spraying treatment at $20 \mu \mathrm{mol} \mathrm{Se}{ }^{-1}$ in both growing seasons, suggesting that most of the effects of salt stress mitigated by Se are a result of a reduction in the uptake of $\mathrm{Na}^{+}$ions. The findings presented here are consistent with those of Kaur and Nayyar (2015), who reported that the underlying reasons for the agonistic effect of $\mathrm{Se}$ on the uptake of sodium are not well understood.

\section{CONCLUSION}

In conclusion, the results of the present study indicate that foliar spraying of $\mathrm{Se}$ at an appropriate dose may represent an effective and practical method of improving lettuce growth and yield and alleviating the adverse effects of salinity stress on plants. Selenium fortification led to significant improvements in the plant leaf number, chlorophyll content and nutrient contents $(\mathrm{N}, \mathrm{P}, \mathrm{K}$ and $\mathrm{Ca}$ ), whereas $\mathrm{Na}$ content is significantly lower than that of the control treatment in lettuce plants. The present study has underlined the importance of Se treatment $\left(20 \mu \mathrm{mol} \mathrm{Se}^{-1}\right)$ as foliar spraying in increasing the lettuce head fresh weight and total yield. This study underlines the urgency for extending this investigation to different crops. 


\section{REFERENCES}

Abul-Soud, M.A. and S.H. Abd-Elrahman (2016). Foliar selenium application to improve the tolerance of eggplant grown under salt stress conditions. International Journal of Plant and Soil Science, 9 (1): $1-10$.

Akladious, S.A. (2012). Influence of different soaking times with selenium on growth, metabolic activities of wheat seedlings under low temperature stress. African Journal of Biotechnology, 11 (82): 14792-14804.

Apolonia, S., K. Andrzej and F. Maria (2015). Involvement of selenium in protective mechanisms of plants under environmental stress conditions - review. Acta Biologica Cracoviensia Series Botanica, 57 (1): 9-20.

Brown, J.D. and O. Lilliland (1964). Rapid determination of potassium, calcium and sodium in plant material and soil extracts flow phosphorus. Proc. Amer. Soc. Hort. Sci., 28: 341-346.

Castillo-Godina, R.G., R. Foroughbakhch-Pournavab and A. BenavidesMendoza (2016). Effect of selenium on elemental concentration and antioxidant enzymatic activity of tomato plants. J. Agr. Sci. Tech., 18: 233-244.

Diao, M., L. Ma, J. Wang, J. Cui, A. Fu and H.Y. Liu (2014). Selenium promotes the growth and photosynthesis of tomato seedlings under salt stress by enhancing chloroplast antioxidant defense system. J. Plant Growth Regul., 33: 671-682.

Djanaguiraman, M., P.V.V. Prasad and M. Seppanen (2010). Selenium protects sorghum leaves from oxidative damage under high temperature stress by enhancing antioxidant defense system. Plant Physiol. Biochem., 48 (12): 999-1007.

Esringu, A., E. Melek, U. Serpil, T. Metin, D. Atilla, E. Sezai and Y. Ertan (2015). Selenium supplementation affects the growth, yield and selenium accumulation in lettuce (Lactuca sativa L.). Compt. Rend. Acad. Bulg. Sci., 68 (6): 801-810.

Feng, R.W., C.Y. Wei and S.X. Tu (2013). The roles of selenium in protecting plantsagainst abiotic stresses. Environmental and Experimental Botany, 87: 58-68.

Ghasemi, Y., G. Kamran, P. Hemattollah and A. Roqieh (2016). Effect of selenium enrichment on the growth, photosynthesis and mineral nutrition of Broccoli. NotSci. Biol., 8 (2): 199-203.

Gomez, K.N. and A.A.Gomez (1984). In "Statistical Procedures for Agricultural Research". $2^{\text {nd }}$ ed., John Wiley and Sons, New York, 68 pp. 
Haghighi, M., A. Reza and A.T.S. Jaime (2014). Low and high temperature stress affect the growth characteristics of tomato in hydroponic culture with $\mathrm{Se}$ and nano-Se amendment. Scientia Horticulturae, 178: $231-240$.

Haghighi, M., S. Atena and P. Mohammad (2016). Effects of selenium as a beneficial element on growth and photosynthetic attributes of greenhouse cucumber. Journal of Plant Nutrition, 39 (10): 14931498.

Hamilton, S.J., (2004). Review of selenium toxicity in the aquatic food chain. Science of the Total Environment, 326 (1-3): 1-31.

Hawrylak-nowak, B. (2008a). Enhanced selenium content in sweet basil (Ocimum basilicum L.) by foliar fertilization. Vegetable Crops Research Bulletin, 69: 63-72.

Hawrylak-Nowak, B. (2008b). Effect of selenium on selected macronutrients in maize plants. J. Elementol., 13 (4): 513-519.

Hawrylak-Nowak B. (2009). Beneficial effects of exogenous selenium in cucumber seedlings subjected to salt stress. Biol. Trace Elem. Res., 132: 259-269.

Inada, K. (1985). Spectral ratio of reflectance for estimating chlorophyll content of leaf. Jpn. J. Crop Sci., 54: 261-265.

Irri, A. (1976). In "Procedures for Routine Analysis of Phosphorus, Iron, Manganese, Aluminium, and Crude Silica in Plant Tissue. Laboratory Manual for Physiological Studies on Rice, 3rd ed. (Yoshida, S., D.A. Forno, J.R. Cock and K.A. Gomez Eds). The Internat. Rice Res. Inst., Los Banos Phillipines, p. 17-23.

Jackson, M.L. (1973). In "Soil Chemical Analysis". Prentice Hall of India Pvt. Ltd. New Delhi, India,187 pp.

Kaur, S. and H. Nayyar (2015). Selenium fertilization to salt-stressed mungbean (Vigna radiata L. Wilczek) plants reduces sodium uptake, improves reproductive function, pod set and seed yield. Scientia Horticulturae, 197: 304-317.

KeLing, H., Z. Ling, W. JiTao and Y. Yang (2013). Influence of selenium on growth, lipid peroxidation and oxidative enzyme activity in melon (Cucumis melo L.) seedlings under salt stress. Acta Soc. Bot. Pol., 82 (3): 193-197.

Khaliq, A., A. Farhena, M. Amar, H. Saddam, G. Mingjian, W. Abdul and U.R. Hafeez (2015). Seed priming with selenium: Consequences for emergence, seedling growth, and biochemical attributes of rice. Biol. Trace Elem. Res., 166: 236-244.

Kim, H., J. Hanseok, J. Jihye and B. Seungjong (2016). Effects of irrigation with saline water on crop growth and yield in greenhouse cultivation. Water, 8 (4): 127; doi: 10.3390/w8040127.

Egyptian J. Desert Res., 67, No. 2, 255-267 (2017) 
Kinraide, T.B. (2003). The controlling influence of cell-surface electrical potential on the uptake and toxicity of selenate $\left(\mathrm{SO}_{4}{ }^{2-}\right)$. Physiol. Plant., 117 (1): 64-71.

Kopsell, D.A., W.M. Randle and H.A. Mills (2000). Nutrient accumulation in leaf tissue of rapid-cycling Brassica oleracea responds to increasing sodium selenate concentrations. J. Plant Nutr., 23 (7): 927-935.

Mao, H., W. Zhaohui and L. Graham (2015). Germination-enhancing and zinc-sparing roles for selenium in broccoli. Acta Agriculturae Scandinavica, Section B - Soil and Plant Science, 65 (2): 141-149.

Melek, E., Y. Ertan and D. Atilla (2012). Mitigation of salt stress in lettuce (Lactuca sativa L. var. Crispa) by seed and foliar 24- epibrassinolide treatments. HortScience, 47 (5): 631-636.

Mozafariyan, M., M.M. Kamelmanesh and B. Hawrylak-Nowak (2016). Ameliorative effect of selenium on tomato plants grown under salinity stress. Archives of Agronomy and Soil Science, 62 (10): 1368-1380.

Nawaz, F., R. Ahmad, M.Y. Ashraf, E.A. Waraich and S.Z. Khan (2015). Effect of selenium foliar spray on physiological and biochemical processes and chemical constituents of wheat under drought stress. Ecotoxicology and Environmental Safety, 113: 191-200.

Pazurkiewicz-Kocot, K., W. Galas and A. Kita (2003). The effect of selenium on the accumulation of some metals in Zea mays L. plants treated with indole-3-acetic acid. Cell. Mol. Biol. Lett., 8: 97-103.

Pezzarossa, B., R. Damiano, L.G. Marialetizia and M. Rossano (2012). Effects of foliar and fruit addition of sodium selenate on selenium accumulation and fruit quality. J. Sci. Food Agric., 92: 781-786.

Poggi, V., A. Alberto, F. Paola and G.P. Pier (2000). Foliar application of selenite and selenite to potato (Solanum tuberosum): Effect of a ligand agent on selenium content of tubers. J. Agric. Food Chem., 48: 4749-4751.

Ramos, S.J., V. Faquin, L.R.G. Guilherme, E.M. Castro, F.W. Ávila, C.E.A. Bastos, C. Oliveira and G.S. Carvalho (2010). Selenium biofortification and antioxidant activity in lettuce plants fed with selenate and selenite. Plant Soil Environ., 56 (12): 584-588.

Rebecca, B. (2004). Soil survey methods manual. Soil Survey Investigations Report. No. 42 Natural Resources Conservation Services.

Snedecor, G.A. and W.G. Cochran (1980). In "Statistical Methods", 7th Ed., the Iowa State Univ., Press, Ames., Iowa, U.S.A.

Sun, H., D. Huaxin, W. Xiaoyun and W. Guohui (2016). Physiological and proteomic analysis of selenium-mediated tolerance to $\mathrm{Cd}$ stress in cucumber (Cucumis sativus L.). Ecotoxicology and Environmental Safety, 133: 114-126.

Egyptian J. Desert Res., 67, No. 2, 255-267 (2017) 
Unlukara, A., B. Cemek, S. Karaman and S. Erşahin (2008). Response of lettuce (Lactuca Sativa var. Crispa) to salinity of irrigation water. New Zealand J. Crop Hortic. Sci., 36 (4): 265-273.

Yao, X., C. Jianzhou and W. Guangyin (2009). Effects of selenium on wheat seedlings under drought stress. Biol. Trace Elem. Res., 130: 283290.

Zhu, Z., Y. Chen, G. Shiand and X. Zhang (2017). Selenium delays tomato fruit ripening by inhibiting ethylene biosynthesis and enhancing the antioxidant defense system. Food Chemistry, 219: 179-184.

Egyptian J. Desert Res., 67, No. 2, 255-267 (2017) 


\section{تأثير نقع البذور والرش الورقي بالسلينيوم على نمو ومحصول الخس تحت الإجهاد الملحي لئومي}

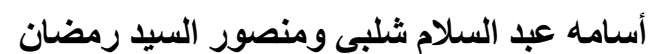

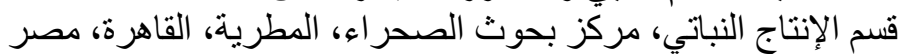

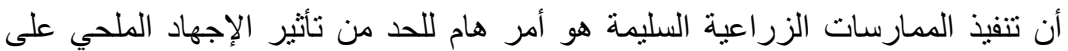

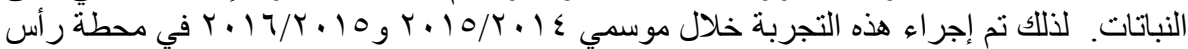

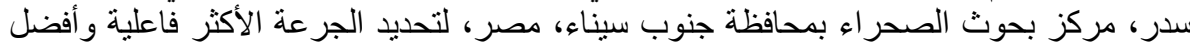

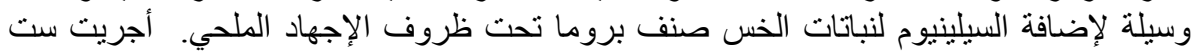

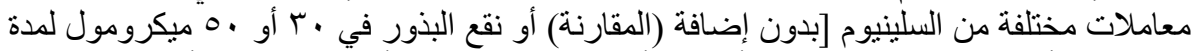

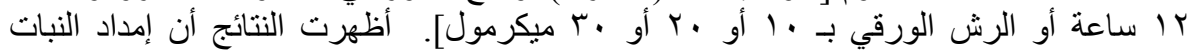

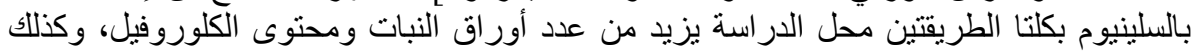

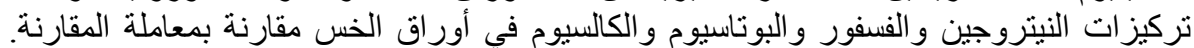

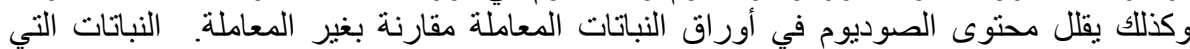

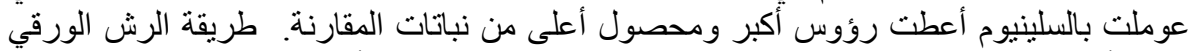

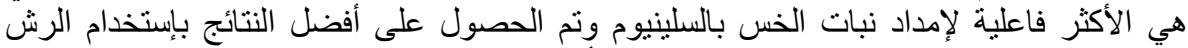

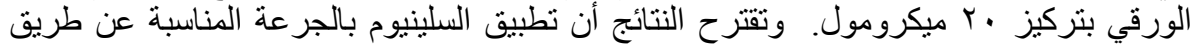
الرش الورقي هي وسيلة فعالة وعملية لتحسين نمو النباتات وتعزيز لـونيز مقاومة نباتات الخس لإجهاد الملوحة.

Egyptian J. Desert Res., 67, No. 2, 255-267 (2017) 